\title{
Microbiological quality of farmed grass carp, bighead carp, Siberian sturgeon, and wels catfish from Eastern Poland
}

\author{
Renata Pyz-Łukasik, Waldemar Paszkiewicz \\ Department of Food Hygiene of Animal Origin, \\ Faculty of Veterinary Medicine, University of Life Sciences in Lublin, Poland \\ renata.pyz@up.lublin.pl
}

Received: March 29, $2018 \quad$ Accepted: June 14, 2018

\begin{abstract}
Introduction: The purpose of this study was to determine the microbiological quality of food fish and its safety for consumers. Material and Methods: The study included 24 fish representing grass carp, bighead carp, Siberian sturgeon, and wels catfish. Specimens were collected in winter. Aerobic bacteria, psychrophilic, Enterobacteriaceae, Staphylococcus spp., and E. coli counts were made, and the presence of Salmonella spp., L. monocytogenes, S. aureus, and other coagulase-positive staphylococci was investigated. Results: The microbiological analysis showed a similar level of aerobic, psychrophilic, and Staphylococcus spp. contamination of the four fish species. The Enterobacteriaceae count was higher in the muscles of grass carp and bighead carp than S. sturgeon and wels catfish. No pathogenic bacteria such as Salmonella spp., E. coli, L. monocytogenes, Staphylococcus aureus, or other coagulase positive staphylococci were found in samples of the examined fish species. Conclusion: The fresh fish examined in this study were of good microbiological quality and there was no health risk for consumers.
\end{abstract}

Keywords: fish quality, food safety, microbiological analysis.

\section{Introduction}

Food fish contain bacteria pathogenic to humans, like Listeria monocytogenes, Salmonella spp., Staphylococcus aureus, and Escherichia coli (3, 12, $13,23,28,30,31)$, and therefore consumption may be entailed risk for consumers. The consumption of raw or insufficiently heat-treated fish causes most outbreaks of food poisoning (13). The quality of raw material and hygiene conditions of processing and storage influence the level of microbiological contamination of fresh fish $(3,4,13,28,31)$.

Food law does not determine microbiological criteria of safety or hygiene in the process of fish production. The International Commission on Microbiological Specification for Foods suggests microbiological criteria for fresh fish (only aerobic plate count and E. coli) (8), but these are not legally enforced and the lack of legislated safety criteria creates potential health risk for consumers. The necessity of monitoring contamination of food fish caused by pathogenic bacteria has been confirmed by other authors $(13,23,30,31)$.
Grass carp (Ctenopharyngodon idella), bighead carp (Aristichthys nobilis), Siberian sturgeon (Acipenser baerii), and wels catfish (Silurus glanis) are food fish and widely aquacultured in many countries (www.fao.org/fishery/statistics/). The purpose of this study was to determine microbiological quality and safety for consumers of these four freshwater food fish.

\section{Material and Methods}

Sampling. The examined fish species were obtained from fish farms located in Eastern Poland in winter. The fish body weight was within the range of $1.4-1.8 \mathrm{~kg}$ for grass carp $(\mathrm{n}=6), 1.7-2.6 \mathrm{~kg}$ for bighead carp $(\mathrm{n}=6), 3.1-4.0 \mathrm{~kg}$ for Siberian sturgeon $(\mathrm{n}=6)$, and $1.4-2.0 \mathrm{~kg}$ for wels catfish $(\mathrm{n}=6)$. The fish ate a natural diet constituted of what was in the pond (variously typical food for herbivorous fish, i.e. grass and bighead carp, and for predatory fish, i.e. Siberian sturgeon and wels catfish) and did not receive any industrial feed. Directly after being caught 
the fish were killed, purchased, and transported to the laboratory. Next, the fish were gutted, placed on sterile trays, and stored in the refrigerator. The temperature during transport was in the $0^{\circ} \mathrm{C}-4^{\circ} \mathrm{C}$ range. The analyses were performed within $24 \mathrm{~h}$ of acquisition and the fish were stored at $0^{\circ} \mathrm{C}-2^{\circ} \mathrm{C}$ until analysis.

Microbiological analysis. $10 \mathrm{~g}$ sample and $90 \mathrm{~mL}$ dilution fluid were homogenised in a stomacher for 2 min at normal speed $(14,15)$. From this dilution, other decimal dilutions were prepared and transferred onto appropriate media in accordance with international guidelines. In order to determine the number of aerobic and psychrophilic bacteria, plate count agar and incubation at $30^{\circ} \mathrm{C}$ for $72 \mathrm{~h}$ and $0^{\circ} \mathrm{C}-4^{\circ} \mathrm{C}$ for 14 days were used, respectively $(2,16)$. For Enterobacteriacae, plates with VRBG medium and incubation at $37^{\circ} \mathrm{C}$ for $24 \mathrm{~h} \mathrm{(17)} \mathrm{were} \mathrm{used} \mathrm{and} \mathrm{for}$ Staphylococcus spp., plates with Baird Parker Agar and incubation at $37^{\circ} \mathrm{C}$ for $48 \mathrm{~h}$ were utilised. Typical colonies of Staphylococcus spp. were confirmed using a coagulase test (18). For E. coli, plates with TBX medium and incubation at $44^{\circ} \mathrm{C}$ for $24 \mathrm{~h}$ were applied (19). The presence of Enterobacteriaceae and Staphylococcus spp. microorganisms was identified with non-reagent assays Enterotest $24 \mathrm{~N}$ and Staphytest 24, and a Multiscan EX test reader. Bacteria counts were presented in logarithms of colony forming unit/g (log $\mathrm{cfu} / \mathrm{g})$.

The presence of Salmonella spp. was determined in accordance with PN-EN ISO 6579:2003 (20). A sample weighing $25 \mathrm{~g}$ added to $225 \mathrm{~mL}$ buffered peptone water was incubated at $37^{\circ} \mathrm{C}$ for $18 \mathrm{~h}$. Further, the following culture media were used: Rappaport-Vassiliadis and incubation at $41.5^{\circ} \mathrm{C}$ for $24 \mathrm{~h}$, then concurrently XLD and BGA and incubation at $37^{\circ} \mathrm{C}$ for $24 \mathrm{~h}$. According to the procedure, if typical colonies are absent on XLD and BGA media, the examination is discontinued.

In order to determine the presence of Listeria spp., examinations were performed in accordance with PN-EN ISO 11290-1:1999 (21). $25 \mathrm{~g}$ of sample in half Fraser broth was incubated at $30^{\circ} \mathrm{C}$ for $24 \mathrm{~h}$. Subsequently, Fraser broth and incubation at $37^{\circ} \mathrm{C}$ for $48 \mathrm{~h}$ were used. Then, concurrently, the Ottaviani and Agosti (ALOA) medium and Oxford medium were incubated at $37^{\circ} \mathrm{C}$ for $24-48 \mathrm{~h}$. Tests were performed to confirm identification of Listeria spp. and L. monocytogenes (Gram staining, catalase test, mobility, sugar fermentation and haemolysis capability test).

Microbiological culture media and tests were sourced from BioMaxima Inc. (Poland), Erba Lachema Ltd. (Czech Republic), and Biomed-Lublin Inc. (Poland).

Statistical analysis. The values of quantitative bacterial contamination (expressed as log) were analysed using Statistica software (Statistica ver. 6.0, Statsoft, Inc., USA). All values are presented as means \pm SD. Statistical differences between the groups were determined by

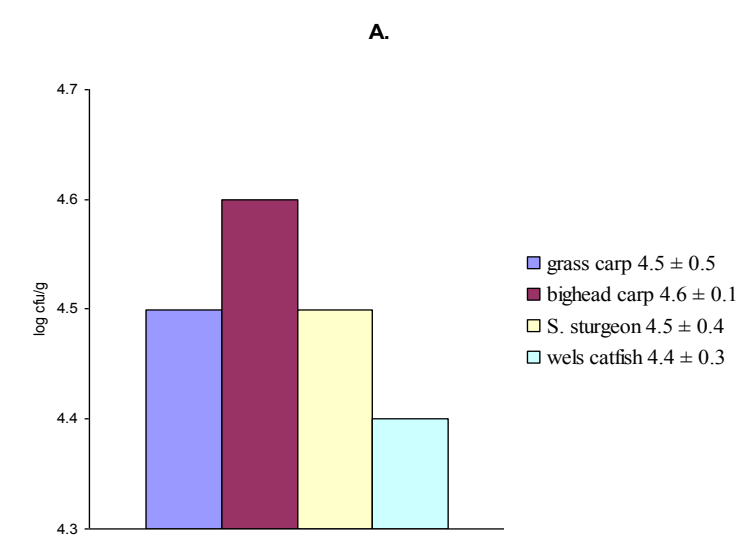

B.

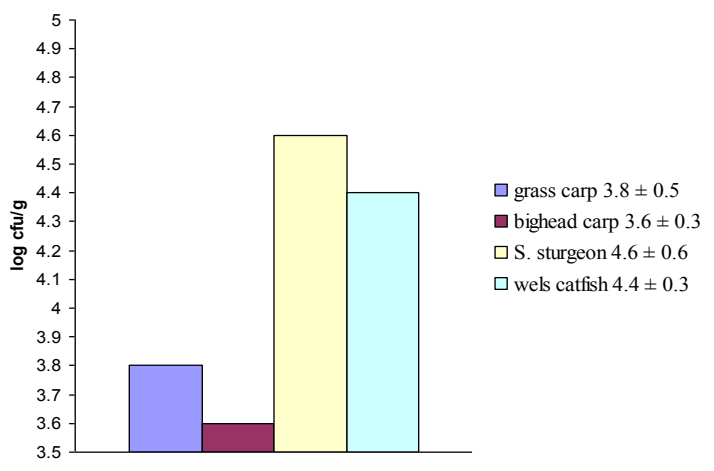

C.

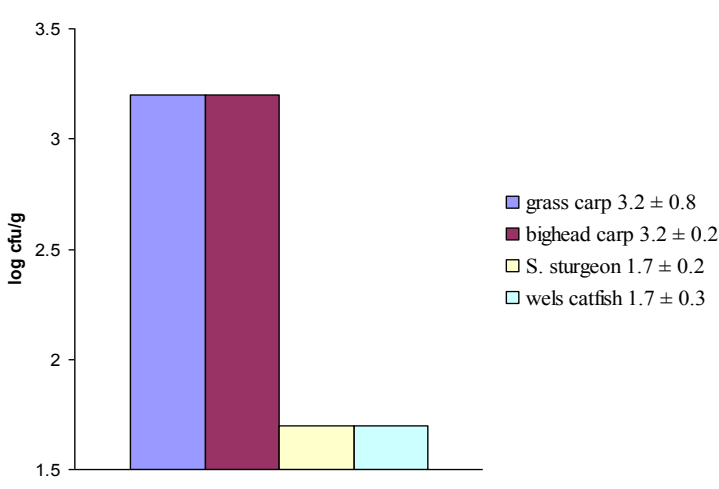

D.

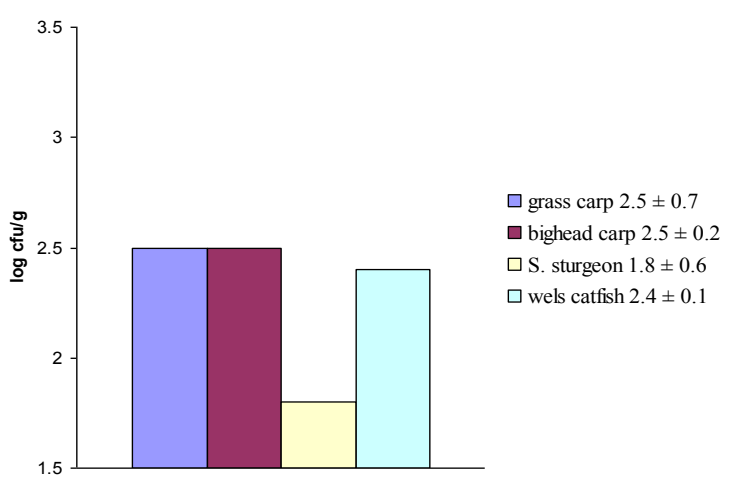

Fig. 1. Microbial analysis of aerobic counts (A), psychrophilic counts (B), Enterobacteriaceae counts (C), and Staphylococcus counts (D) (mean $\pm \mathrm{SD}, \log \mathrm{cfu} / \mathrm{g}$ ) 
one-way analysis of variance (ANOVA) and Tukey's multiple comparison post hoc test at $\mathrm{P}<0.05$. Pearson's correlation coefficient $(r)$ was determined between the levels of particular bacteria. $\mathrm{P}<0.05$ was assumed as statistically significant for all correlations.

\section{Results}

The results of microbiological analysis are presented in Fig. 1. The aerobic bacteria counts in the muscle tissues of the examined fish species were similar $(\mathrm{P}>0.05 ; 4.4-4.6 \log \mathrm{cfu} / \mathrm{g})$. The psychrophilic bacteria counts $(\mathrm{P}>0.05)$ in the muscle tissues of grass carp and bighead carp were lower (3.8 and 3.6 log $\mathrm{cfu} / \mathrm{g}$, respectively), and in Siberian sturgeon and wels catfish (4.6 and $4.4 \log \mathrm{cfu} / \mathrm{g}$, respectively) they were close to the total counts of aerobic bacteria. The Enterobacteriaceae counts were significantly higher $(\mathrm{P}<0.05)$ in the muscle tissues of herbivorous species i.e. grass carp and bighead carp than in predatory species i.e. S. sturgeon and wels catfish (3.2 log cfu/g and $1.7 \log \mathrm{cfu} / \mathrm{g}$, respectively). The levels of Staphylococcus spp. contamination in the muscle tissues of grass carp, bighead carp, Siberian sturgeon, and wels catfish were comparable $(\mathrm{P}>0.05 ; 1.8-2.5 \mathrm{log}$ cfu/g). No Listeria monocytogenes, Salmonella spp., Staphylococcus aureus, nor other coagulase-positive staphylococci and E. coli (below $1 \log \mathrm{cfu} / \mathrm{g}$ ) were found in samples of the examined fish species.

No statistically significant correlations $(\mathrm{P}>0.05)$ between the levels of particular bacteria were found.

\section{Discussion}

The aerobic plate count (APC) microbiological limits recommended by the ICMSF for fresh fish are specified as the threshold value for the number of bacteria $\mathrm{m}=5 \times 10^{5}$ (i.e. $\log 5.7$ ) and the maximum number of bacteria $\mathrm{M}=10^{7}$ (i.e. $\log 7.0$ ) per gram or per $\mathrm{cm}^{2}$. APC indicates the general quality of fish (8). The obtained APC level in the muscles of these four fish species indicated good quality. Li et al. (10) reported that the bacterial flora of newly-caught fish is directly related to the fish habitat and does not depend on the species as such. Apart from the environment, the fishing method and suitable on-board handling procedures also contribute to the microbiological load of fish muscles (26). The aerobic plate count of the whole ungutted rainbow trout (Onchorynchus mykiss) was lower than the values determined in the current study (4). However, a similar aerobic plate count (4.24 log cfu/g) was stated in gutted and ungutted sutchi catfish (Pangasianodon hypophthalmus) (27) and a slightly higher number $(\log 5.1 \mathrm{cfu} / \mathrm{g})$ was reported in the case of whole gutted pearlspot (Etroplus suratensis Bloch) (22).

Bacterial spoilage in refrigerated fish under aerobic storage conditions is caused by gram-negative psychrotrophic microorganisms (24). The higher count of these bacteria in fresh fish could be explained as a contamination caused by handling processes because these microorganisms are also commonly present on board vessels, in boxes, and on ice (cit. 26). Ravi Sankar et al. (22) reported that the psychrotrophic count was slightly lower than the aerobic count in the fresh pearlspot (Etroplus suratensis Bloch) (4.62 log $\mathrm{cfu} / \mathrm{g}$ and $5.1 \log \mathrm{cfu} / \mathrm{g}$, respectively). During refrigerated storage the psychrotrophic bacteria dominate mesophilic ones. The psychrotrophic count exceeded the mesophilic count in all samples of pearlspot after 1 week of storage $\left(0^{\circ}-2^{\circ} \mathrm{C}\right)$. In the four examined fish species, the numbers of psychrophilic bacteria were close to the numbers of aerobic bacteria, which could indicate poor sanitary conditions in the handling process. A higher content of psychrophilic bacteria in the muscles of fresh fish may result in shorter shelf life.

Enterobacteriaceae serve as an indicator of the hygiene of food acquisition or production (5). The Enterobacteriaceae count was higher by $1.5 \log$ in the muscle tissues of grass carp and bighead carp (herbivorous species) than in Siberian sturgeon and wels catfish (predatory species). Probably the hygiene standard during acquisition or production for the examined herbivorous fish species was poorer than for the predatory fish species. In the examined fish species Klebsiella pneumoniae subsp. ozaenae was most commonly isolated. The presence of this bacteria in fresh fish indicates faecal contamination of the water used for processing (28). In Poland, food law does not specify an acceptable limit of Enterobacteriaceae for fresh fish. The Enterobacteriaceae concentration in the herbivorous species would be unacceptable if compared to the limit of $10^{2} \mathrm{CFU} / \mathrm{g}$ established in Croatian microbiological standards for fresh fish (25). The level of Enterobacteriaceae determined for herbivorous fish species in the present study was higher than in whole ungutted and gutted catfish (2.3 log cfu/g) (27) and the whole ungutted trout (below $2 \log \mathrm{cfu} / \mathrm{cm}^{2}$ ) (4). A similar contamination level to that stated for Enterobacteriaceae in herbivorous fish species was found in farmed rainbow trout (12). The role of Enterobacteriaceae in the microflora of fish and its spoilage potential need to be taken into account especially in those cases where either contaminated waters or delay in chilling feature in the process of fishing (27). Ravi Sankar et al. (22) reported that even with strict temperature control, growth of Enterobacteriaceae was noticed in pearlspot packed under a modified atmosphere indicating that additional hurdles may be necessary to ensure safety. A high level of product contamination with Enterobacteriaceae shortens its shelf life (11).

Non-pathogenic staphylococci may be allochthonous microflora which is washed out from contaminated soil or air into the water ponds (24). This type of bacteria was found in the muscles of the four 
examined fish species in low numbers. Within this group Staphylococcus warnei, Staphylococcus vitulinus, Staphylococcus epidermidis, and Staphylococcus xylosus were the species most commonly isolated. Staphylococcus aureus is used as an indicator of hygienic conditions during fish processing. Freshly caught fish should not contain $S$. aureus (13). In this study, the examined fish species did not contain of $S$. aureus. However, $S$. aureus was found in the muscles of fresh herring (3.96 log cfu/g) (9) and fresh trout (1.3 log cfu/g) (12). Moreover $S$. aureus $(<50 \mathrm{cfu} / \mathrm{g}$ ) was detected in fresh pearlspot (Etroplus suratensis) during storage $\left(0^{\circ} \mathrm{C}-2^{\circ} \mathrm{C}\right)$ in the air and under different modified atmospheres (22).

No bacteria of the genus Salmonella, E. coli, or Listeria monocytogenes were found in the samples of the examined fish species. The absence of these pathogens in the muscles of the examined grass carp, bighead carp, S. sturgeon, and wels catfish showed that the microbiological quality of water in these farms and distribution conditions were satisfactory.

Fish may carry Salmonella if caught in polluted waters (29) but fish from non-polluted waters do not contain the bacteria. The presence of these bacteria in fish is due to handling, e.g. from human carriers or poor disinfection. The risk of Salmonella contamination is higher in freshwater fish than in marine fish (cit. 1, cit. 29). Wogu and Maduakor (28) reported that the presence of Salmonella spp. in the fresh fish is an indication of faecal contamination of water used for processing.

E. coli is viewed as a sanitary hazard and represents a health risk to consumers when pathogenic strains are present. The occurrence of non-pathogenic $E$. coli in fish should nevertheless send warning signals to public health institutions, recognising the bacterium's well-known role as an indicator of faecal contamination, which may also point to the presence of some other enteric pathogens (6). High E. coli counts seem to be accredited to its widespread presence in nearly all natural milieu including water and air as well as human skin (28).

L. monocytogenes is commonly present in fresh water, coastal water, and live fish found there (7). Processing and handling of fish may also entail contamination or recontamination $(3,7)$.

Consequently, the desired safety measures may be guaranteed when fresh fish is processed hygienically, maintaining rigid standards, including standards of plant hygiene at critical control points and product cooling to about $2^{\circ} \mathrm{C}(13,28)$.

In conclusion, in the muscles of grass carp, bighead carp, Siberian sturgeon, and wels catfish no bacterial pathogens such as Salmonella spp., E. coli, L. monocytogenes, Staphylococcus aureus, or other coagulase-positive staphylococci were shown. The aerobic bacteria and $E$. coli counts in the muscles of the four examined fish species were below acceptable limits for fresh fish set by the International
Commission on Microbiological Specification for Foods. Thus, the fresh fish analysed in this study were of good microbiological quality and there was no health risk for consumers. The number of psychrophilic bacteria in all examined fish species and Enterobacteriaceae in the grass carp and bighead carp indicates a hygiene deficiency during acquisition or handling.

Conflict of Interests Statement: The authors declare that there is no conflict of interests regarding the publication of this article.

Financial Disclosure Statement: This research was financed by the Faculty of Veterinary Medicine, University of Life Sciences in Lublin.

Animal Rights Statement: None required.

\section{References}

1. Binsi P.K., Viji P., Visnuvinayagam S., Ninan G., Sangeeta G., Triveni A., Ravishankar C.N.: Microbiological and shelf life characteristics of eviscerated and vacuum packed freshwater catfish (Ompok pabda) during chill storage. J Food Sci Technol 2015, 52, 1424-1433.

2. Burbianka M., Pliszka A., Burzyńska H.: Food Microbiology, PZWL, Warszawa, 1983.

3. Chanpiwat P., Sthiannopkao S., Widmer K., Himeno S., Miyataka H., Vu N.U., Tran V.V., Pham T.T.: Assessment of metal and bacterial contamination in cultivated fish and impact on human health for residents living in the Mekong Delta. Chemosphere 2016, 163, 342-350.

4. Chytiri S., Chouliara I., Savvaidis I.N., Kontominas M.G.: Microbiological, chemical, and sensory assessment of iced whole and filleted aquacultured rainbow trout. Food Microbiol 2004, 21, 157-165.

5. Commission Regulation (EC) No 2073/2005 of 15 November 2005 on microbiological criteria for foodstuffs. OJ L 338 , 22.12.2005, p. 1 .

6. Costa R.A.: Escherichia coli in seafood: A brief overview. Adv Biosci Biotechnol 2013, 4, 450-454.

7. Huss H.H., Jørgensen L.V., Vogel B.F.: Control options for Listeria monocytogenes in sea foods. Int J Food Microbiol 2000, 62, 267-274.

8. International Commission on Microbiological Specifications for Foods (ICMSF). Microorganisms in Foods 2. Sampling for microbiological analysis: Principles and specific applications. Blackwell Scientific Publications, London, 1986.

9. Kukułowicz A.: Influence of preservation technology on the microbiological quality of herrings. Zeszyty Naukowe Akademii Morskiej w Gdyni 2011, 68, 42-46

10. Li T., Li J., Hu W.: Changes in microbiological, physicochemical and muscle proteins of post mortem large yellow croaker (Pseudosciaena crocea). Food Control 2013, 34, 514-520.

11. Molska I.: Some problems of the presence and importance of the Enterobacteriaceae in food products. Przem Spoż 2007, 3, 30-32.

12. Ninan G., Lalitha K.V., Zynudheen A.A., Joseph J.: Effect of chilling on microbiological, biochemical, and sensory attributes of whole aquacultured rainbow trout (Oncorhynchus mykiss Walbaum, 1972). J Aquac Res Dev 2011, S5:001. doi:10.4172/2155-9546.S5-001. 
13. Novotny L., Dvorska L., Lorencova A., Beran V., Pavlik I.: Fish: a potential source of bacterial pathogens for human beings. Vet Med-Czech 2004, 49, 343-358.

14. PN-EN ISO 7218:2008 Microbiology of food and animal feeding stuffs - General requirements and guidance for microbiological examination.

15. PN-EN ISO 6887-3:2005 Microbiology of food and animal feeding stuffs - Preparation of test samples and decimal dilutions for microbiological examination - Part 3: Specific rules for the preparation of fish and fishery products.

16. PN-EN ISO 4833-2:2013-12 Microbiology of food and animal feeding stuffs - Horizontal method for the enumeration of microorganisms - Colony-count at 30 degrees $\mathrm{C}$ by the surface plating technique.

17. PN-ISO 21528-2:2005 Microbiology of food and animal feeding stuffs - Horizontal method for the detection and enumeration of Enterobacteriaceae - Part 2: Colony-count method.

18. PN-EN ISO 6888-1:2001 Microbiology of food and animal feeding stuffs - Horizontal method for the enumeration of coagulase-positive staphylococci (Staphylococcus aureus and other species) - Part 1: Technique using Baird-Parker agar medium.

19. PN-ISO 16649-2:2004 Microbiology of food and animal feeding stuffs - Horizontal method for the enumeration of $\beta$-glucuronidase-positive Escherichia coli - Part 2: Colony-count technique at 44 degrees $\mathrm{C}$ using 5-bromo-4-chloro-3-indolyl $\beta$-D-glucuronide.

20. PN-EN ISO 6579:2003 Microbiology of food and animal feeding stuffs - Horizontal method for the detection of Salmonella spp.

21. PN-EN ISO 11290-1:1999 Microbiology of food and animal feeding stuffs - Horizontal method for the detection and enumeration of Listeria monocytogenes - Part 1: Detection method.

22. Ravi Sankar C.N., Lalitha K.V., Leema Jose, Manju S., Gopal T.K.S.: Effect of packaging atmosphere on the microbial attributes of pearlspot (Etroplus suratensis Bloch) stored at $0-2^{\circ} \mathrm{C}$. Food Microbiol 2008, 25, 518-528.

23. Terentjeva M., Eizenberga I., Valciņa O., Novoslavskij A., Strazdiņa V., Bērziņš A.: Prevalence of foodborne pathogens in freshwater fish in Latvia. J Food Prot 2015, 78, 2093-2098.

24. Tkaczewska J., Kulawik P., Migdał W.: The quality of rainbow trout (Oncorhynchus mykiss) cultured in various Polish regions. Ann Anim Sci 2015, 15, 527-539.

25. Topic Popovic N., Benussi Skukan A., Dzidara P., CozRakovac R., Strunjak-Perovic I., Kozacinski L., Jadan M., BrlekGorski D.: Microbiological quality of marketed fresh and frozen seafood caught off the Adriatic coast of Croatia. Vet Med 2010, $55,233-241$

26. Tzikas Z., Amvrosiadis I., Soultos N., Georgakis Sp.: Seasonal variation in the chemical composition and microbiological condition of Mediterranean horse mackerel (Trachurus mediterraneus) muscle from the North Aegean Sea (Greece). Food Control 2007, 18, 251-257.

27. Viji P., Tanuja S., Ninan G., Lalitha K.V., Zynudheen A.A., Binsi P.K., Srinivasagopal T.K.: Biochemical, textural, microbiological, and sensory attributes of gutted and ungutted sutchi catfish (Pangasianodon hypophthalmus) stored in ice. J Food Sci Tech 2015, 52, 3312-3321.

28. Wogu M.D., Maduakor C.C.: Evaluation of microbial spoilage of some aquacultured fresh fish in Benin City Nigeria. Ethiopian J Environ Studies Management 2010, 3, 18-22.

29. Youssef H., EL-Timawy A.K., Ahmed S.: Role of aerobic intestinal pathogens of fresh water fish in transmission of human diseases. J Food Prot 1992, 55, 739-740.

30. Yücel N., Balci S.: Prevalence of Listeria, Aeromonas, and Vibrio species in fish used for human consumption in Turkey. J Food Prot 2010, 73, 380-384.

31. Zadernowska A., Łaniewska-Trokenheim Ł., Chajęcka W.: Detection of Listeria monocytogenes and Salmonella sp. rods in fish and fish products using the mini Vidas system. Med Weter 2010, 66, 264-267. 